\title{
Aspek Prasejarah Di Wilayah Kabupaten Tabalong Provinsi Kalimantan Selatan
}

\section{Retno Handini; Harry Widianto}

Keywords: distribution, sites, prehistory, tradition, description, survey

\section{How to Cite:}

Kosasih, E. (1998). Aspek Prasejarah Di Wilayah Kabupaten Tabalong Provinsi Kalimantan Selatan. Berkala Arkeologi, 18(2), 92-101. https://doi.org/10.30883/jba.v18i2.786

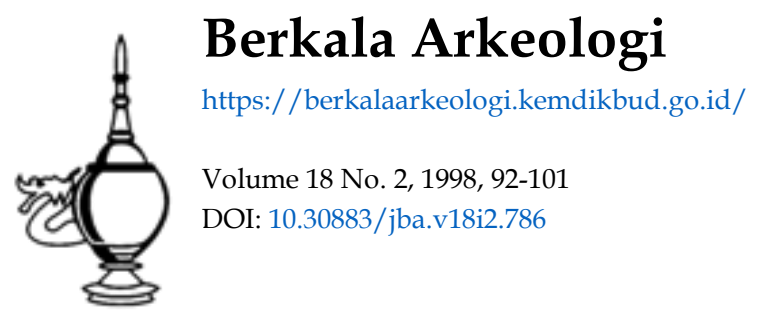

\section{(c) (†)(2)}

This work is licensed under a Creative Commons Attribution-NonCommercial-ShareAlike 4.0 International License. 


\title{
ASPEK PRASEJARAH DI WILAYAH KABUPATEN TABALONG PROVINSI KALIMANTAN SELATAN
}

\author{
E.A. Kosasih \\ (Pusat Penelitian Arkeologi Nasional)
}

\section{Pendahuluan}

Situs-situs prasejarah sampai saat ini telah banyak diketahui sebarannya di seluruh kawasan Indonesia. Kegiatan teknologi tertua dari masyarakat prasejarah berupa alatalat berburu dan mengumpul makanan tingkat sederhana (paleolitik) telah dilacak persebarannya mencapai Sumatera Utara (Nias), Sumatera Selatan (Lahat), Bengkulu (Tambangsawah), Lampung (Kalianda), Kalimantan Selatan (Awangbangkal), Sulawesi Selatan (Cabbenge), Bali (Sembiran dan Trunyan), NTT (Sumbawa, Flores, Timor), Jawa Timur (Punung), Jawa Barat (Sukabumi), dan Jawa Tengah (Gombong) (Soejono, 1984). Demikian pula dengan teknologi alat-alat batu yang lebih kemudian seperti pada masa berburu dan mengumpul makanan tingkat lanjut (mesolitik) dan bercocok tanam (neolitik), serta perundagian telah banyak sekali diteliti dan ditemukan di wilayah Indonesia.

Wilayah administrasi Kalimantan Selatan sebagai bagian dari Nusantara tentunya juga mempunyai potensi yang cukup tinggi bagi penelitian arkeologi. Namun demikian, hingga tahun 1994 masih terdapat jurang yang memisahkan matarantai prasejarah antara wilayah Kalimantan Selatan dengan wilayah-wilayah lainnya di Indonesia. Selain situs paleolitik Awangbangkal, belum ditemukan situs prasejarah yang pasti di wilayah ini. Hal ini disebabkan kurangnya intensitas penelitian prasejarah di kawasan Kalimantan Selatan. Oleh karena itu penelitian prasejarah yang intensif dan mendalam sangat diperlukan untuk dapat mengisi kekosongan era prasejarah yang ada di daerah ini. Penanganan penelitian yang lebih mendalam di daerah ini mulai direalisasi sejak berdirinya Balai Arkeologi Banjarmasin pada tahun 1994.

Laporan tentang peninggalan prasejarah di wilayah Kalimantan Selatan pertama kali dilakukan oleh H. Kupper dan Toer Soetardjo berupa artefak batu paleolitik di aliran Sungai Riam Kanan (Awangbangkal). Kemudian pada tahun 1985 Pusat Penelitian Arkeologi Nasional di bawah pimpinan R.P. Soejono melakukan cek ulang di Situs Riam Kanan dan memberikan indikasi adanya situs paleolitik. Tahun 1994 Tim Balai Arkeologi Banjarmasin, sesuai dengan laporan penduduk, melakukan penelitian di Desa Jambu Hilir Kecamatan Kandangan, Kabupaten Hulu Sungai Selatan. Penelitian berhasil menemukan sejumlah gerabah berbentuk musa (wadah pelebur logam), manik-manik dari tanah liat, manik-manik emas, dan kapak batu yang diduga dari 
tradisi prasejarah. Situs terakhir tersebut kemudian diekskavasi pada tahun 1995, dan berhasil menemukan sisa permukiman yang terutama dicirikan oleh akumulasi pecahan gerabah. Berdasarkan asosiasi dengan temuan lainnya seperti wadah pelebur logam dan manik-nranik, ditafsirkan bahwa situs ini berasal dari periode perundagian (Nasruddin, 1996). Informasi selanjutnya tentang situs prasejarah diberikan oleh masyarakat di Artain berupa kapak neolitik yang saat ini disimpan di Museum Lambung Mangkurat. Dalam aktivitas penelitian lapangannya, Balai Arkeologi Banjarmasin telah melakukan penggalian secara intensif di Gua Babi, Kecamatan Muara Uya (Kabupaten Tabalong) sejak tahun 1995 hingga 1998. Hasil penelitian ini sangat positif bagi upaya pemahaman situs hunian gua di Kalimantan selatan, yang sementara dari pertanggalan C-14 pada level $70-80 \mathrm{~cm}$ dari permukaan tanah diperoleh angka 5.000 tahun (Widianto et al., 1997). Selain itu juga laporan dari Kantor Departemen Pendidikan dan Kebudayaan Kabupaten Tabalong memberikan data tambahan tentang kubur-kubur tradisi prasejarah dari masyarakat Suku Dayak.

Berangkat dari permasalahan tersebut, maka untuk melacak lebih lanjut potensi arkeologis yang ada di wilayah Kalimantan Selatan --khususnya di Kabupaten Tabalong-- akan disajikan hasil-hasil penelitian prasejarah (dan tradisinya) yang telah dilakukan selama ini oleh Balai Arkeologi Banjarmasin bekerja sama dengan Pusat Penelitian Arkeologi Nasional. Hasil penelitian ini perlu diungkapkan, untuk lebih memahami potensi arkeologi di wilayah Kabupaten Tabalong.

\section{Potensi Arkeologis di Wilayah Tabalong}

Kabupaten Tabalong terletak pada wilayah geografis $2^{\circ} 9^{\prime} 33.56^{\prime \prime}$ Lintang Selatan dan $115^{\circ} 22^{\prime 2} .03^{\prime \prime}$ Bujur Timur, yang diapit oleh jajaran Pegunungan Meratus di arah barat, timur, dan utara dengan ketinggian berkisar antara 256 meter di atas muka laut (Gunung Batu Aji) sampai 1.380 meter (Gunung Sarempakang). Secara administratif daerah ini mempunyai luas lahan $3.946 \mathrm{~km}^{2}$ yang dibagi menjadi 10 kecamatan terdiri atas Banua Lawas, Pugaan, Kelua, Muara Harus, Tanta, Tanjung, Murung Pudak, Haruai, Upau, Muara Uya dan Jaro. Selain itu wilayah ini dibatasi oleh Propinsi Kalimantan Timur di sebelah utara dan timur, Propinsi Kalimantan Tengah di sebelah barat, dan Kabupaten Hulu Sungai Utara di sebelah selatan.

Berdasarkan pada penelitian yang telah dilakukan, maka dapat dilacak adanya situssitus prasejarah yang terdapat di wilayah Tabalong. Situs-situs prasejarah tersebut merupakan situs hunian gua (Gua Babi) dan tradisi prasejarah, yang terutama merupakan hasil budaya dari komunitas Dayak Lawangan. 


\section{A. Situs Prasejarah.}

Penelitian Balai Arkeologi Banjarmasin bekerjasama dengan Pusat Penelitian Arkeologi Nasional di Kabupaten Tabalong, Kalimantan Selatan diawali dengan mengadakan survei pada tahun 1995. Survei ini bertujuan antara lain untuk memperoleh data tentang aktivitas kehidupan prasejarah berciri mesolitik dan neolitik, sehubungan dengan eksistensi jajaran pegunungan karst, bagian dari Pegunungan Meratus. Berdasarkan survei tersebut, berhasil ditemukan enam buah gua meliputi Gua Tulang, Gua Kelelawar, Gua Akar, Gua Hanau, Gua Kariwaya, dan Gua Babi. Sisa-sisa aktivitas hunian gua masa prasejarah telah secara kuat ditemukan di Gua Babi yang terletak di Desa Randu (Kecamatan Muara Uya), yang dicirikan oleh temuan serpihan-serpihan batu rijang (beberapa di antaranya menunjukkan pemakaian secara intensif), fragmen gerabah berhias dengan hiasan arkaik (duri ikan), dan juga himpunan cangkang Gastropoda yang telah dipotong bagian apex-nya (Prasetyo dan Widianto, 1996). Untuk menindaklanjuti penelitian survei tersebut, maka dilakukan ekskavasi pada Gua Babi.

Berdasarkan hasil ekskavasi di Gua Babi sejak tahun 1996 telah memberikan interpretasi yang sangat bermanfaat bagi pengungkapan sisi gelap prasejarah di Kalimantan Selatan. Secara ringkas, hasil penelitian dapat disimpulkan sebagai berikut (Widianto et al., 1997) :

1. Gua Babi merupakan sebuah situs hunian gua prasejarah, yang untuk pertama kali ditemukan dan diteliti secara intensif di Kalimantan Selatan. Data ekskavasi menunjukkan bahwa situs ini telah dihuni sejak tingkatan mesolitik hingga tingkatan neolitik, dengan ciri budaya berupa artefak batu, tulang, dan gerabah.

2. Pada masa okupasi manusia prasejarah di gua ini telah cukup intensif dimanfaatkan untuk aktivitas sehari-hari. Data sementara menunjukkan bahwa bagian teras hingga bagian utara teras, telah dieksploitasi secara maksimal, terbukti dengan ditemukannya lapisan budaya berupa shell-bed. Perapian untuk berbagai keperluan --di antaranya memasak makanan-- telah ditemukan di tengah teras gua, sehingga diketahui bahwa bagian tengah teras merupakan salah satu pusat kegiatan harian. Di lain pihak jejak-jejak aktivitas manusia di bagian selatan teras belum ditemukan.

3. Dalam aktivitas sehari-hari, pendukung budaya Gua Babi telah mengeksploitasi sumberdaya makanan di sekitar gua. Salah satu makanan utamanya adalah siput air tawar, yang diperoleh dari areal depan gua dan sekitarnya, yang dulunya ditafsirkan sebagai lingkungan rawa/payau ataupun sungai. Siput-siput ini diperoleh bagian ujungnya, untuk memudahkan mengeluarkan dagingnya, dan dimasak dalam perapian yang ditemukan di tengah gua. Selain mengeksploitasi 
siput air tawar, penghuni gua juga telah melakukan perburuan binatang dan meramu makanan yang dibuktikan dengan temuan akumulasi tulang-tulang binatang di tengah himpunan artefak batu (yang sangat melimpah). Sebagian dari tulang-tulang itu dibuat artefak.

4. Dalam memperoleh bahan dasar untuk pembuatan alat batu, pendukung budaya Gua Babi harus keluar dari lingkungan gua karena bahan-bahan alat tersebut (basalt, rijang, obsidian, jaspis, dan batuan kersikan lainnya) tidak terdapat di sekitar gua. Bahan-bahan tersebut diperoleh dari endapan alluvial Sungai Uya, yang terletak sekitar 1.5 kilometer dari lokasi gua, yang merupakan rombakan batuan penyusun di daerah Gunung Batumanau dan Gunung Lumut, bagian dari Pegunungan Meratus.

5. Unsur-unsur budaya alat batu dan alat tulang dari Gua Babi menunjukkan keterkaitan dengan unsur-unsur budaya kehidupan di Sulawesi Selatan. Di lain pihak, komponen gerabahnya menunjukkan pengaruh dari tradisi Bau-Malaya, tradisi gerabah yang berkembang di Asia Tenggara. Situasi seperti ini menunjukkan bahwa perkembangan budaya Gua Babi sangat "inheren" terhadap perkembangan budaya di sekelilingnya, baik dalam konteks lokal maupun regional.

6. Berdasarkan ciri-ciri kulturalnya --baik teknologi, tipologi, maupun model hidup mereka-- ditafsirkan bahwa budaya Gua Babi menempati suatu tahapan budaya prasejarah dalam tingkat mesolitik hingga awal neolitik. Hasil pertanggalan Situs Gua Babi melalui metode C-14 dari sampel arang kotak D11-D12 pada kedalaman 70-80 em, yaitu : $5.050 \pm 100 \mathrm{BP}$. Dengan demikian, umur absolut Situs Gua Babi pada level tersebut adalah 5.000 tahun.

\section{B. Tradisi Prasejarah}

Hadirnya peti-peti kayu maupun wadah-wadah keramik sebagai tempat penyimpanan rangka manusia menunjukkan bahwa masyarakat Suku Dayak pada masa lalu (saat ini masyarakat Suku Dayak golongan muda sudah tidak mengenal lagi), masih menggunakan tradisi prasejarah dalam sistem penguburan mereka. Ada beberapa proses penguburan yang dilakukan masyarakat Suku Dayak khususnya Dayak Lawangan, yaitu jikalau seseorang meninggal, mayatnya kemudian dikuburkan di dalam tanah. Setelah beberapa tahun, ketika keluarga yang ditinggalkan sudah mengumpulkan persiapan upacara untuk mengantar arwah ke dunia lain, maka antara 4-8 tahun kemudian kubur digali kembali untuk dipindahkan ke tempat lain. Dalam proses pemindahan ada beberapa jenis rangka yang diambil seperti tengkorak atau 
bagian tulang kaki. Tengkorak maupun tulang kaki tersebut lalu dipindahkan ke media lain, yaitu:

- Di dalam peti kayu dari ulin yang bertutup dan didirikan di atas dua tiang. Peti ini oleh masyarakat suku Dayak disebut dengan istilah Tabela.

- Di dalam ceruk-ceruk gua.

- Di dalam tempayan/guci keramik yang didirikan di atas tiang, dengan bentuk penyangga yang bervariasi. Jenis penguburan sekunder ini oleh masyarakat setempat disebut dengan istilah Kariring dan Teloh.

Dalam pelaksanaan kegiatan tersebut tentu saja diperlukan aturan-aturan dan upacaraupacara tertentu seperti menyembelih sapi, babi dan ayam. Mengenai tradisi penguburan pada masyarakat Dayak Lawangan yang antara lain berada di Kabupaten Tabalong ini telah diteliti secara lebih mendalam oleh Bidang Prasejarah Pusat Penelitian pada bulan Agustus 1997 (Handini et al., 1997), yang antara lain menyebutkan adanya 3 tingkatan kubur sekunder, yaitu rumah raung, tabela, dan kariring.

Temuan tradisi prasejarah yang berhasil didata dalam penelitian kami terdapat di daerah aliran sungai dan daerah pegunungan. Bukti-bukti adanya tradisi prasejarah yang ditemukan di daerah aliran sungai adalah berupa peti kubur dari kayu ulin yang ditemukan di tepi Sungai Tabalong, dan sekarang disimpan di Kantor Departemen Pendidikan dan Kebudayaan Kecamatan Murung Pudak. Peti kubur kayu (tebela) ini ditemukan sudah lepas dari konteksnya, tanpa ada lagi tiang penyangganya. Tebela berbentuk persegi panjang berukuran panjang $177 \mathrm{~cm}$ dan lebar $35 \mathrm{~cm}$, serta tinggi 25 $\mathrm{cm}$. Dibuat dari kayu utuh yang dilubang pada bagian tengahnya dengan bentuk sisi tidak sama. Sisi satu berbentuk segi empat, sedangkan sisi lainnya membulat. Masingmasing sisinya mempunyai tonjolan sebagai tempat untuk memacangkan tiangnya.

Sementara tradisi prasejarah yang berhasil didata di daerah perbukitan berpusat di Gunung Malui terutama di Gua Malui. Gua Malui merupakan salah satu gua yang terletak pada Gunung Malui, secara administratif terletak di Desa Dambung Raya, Kecamatan Haruai. Situs ini terletak sekitar 72 kilometer di sebelah utara Kota Tanjung (Ibukota Kabupaten Tabalong), dengan topografi yang berbukit-bukit dan mempunyai ketinggian rata-rata 125 meter dari permukaan laut serta kemiringan berkisar antara $0^{\circ}-15^{\circ}$. Sumber air yang mengalir sepanjang tahun adalah Sungai Tabalong dengan anak Sungai Duut, Durui, dan Kuyai. Gua Malui terletak di sebelah timurlaut Gunung Kesali yang mempunyai ketinggian sekitar 772 meter dari permukaan laut. Gua yang terletak sekitar 10 meter dari muka tanah ini mempunyai panjang sekitar 20 meter dengan dua buah mulut yang bertolak belakang. Orientasi gua menghadap baratdaya-timurlaut dengan lantai gua yang relatif datar dan rata serta mempunyai luas sekitar $6 \times 20$ meter. Gua dengan beberapa ceruk kecil yang 
menjorok ke masing-masing sisinya itu mempunyai tingkat kelembaban yang rendah serta intensitas cahaya matahari yang cukup tinggi (80\%).

Tradisi prasejarah yang berhasil didata di dalam Gua Malui didominasi dengan temuan sejumlah tengkorak yang diletakkan pada ceruk dinding batu kapur serta di dalam tempayan, dan peti kayu bertutup. Terdapat 8 kelompok konsentrasi sisa-sisa rangka manusia yang kami kelompokkan menurut abjad dari A sampai $\mathrm{H}$.

\section{Kelompok $A$}

Terletak di tingkat dua ceruk dinding gua sebelah sisi baratlaut. Terdiri dari 4 buah tengkorak manusia yang berjajar dan dicirikan sebagai berikut ini:
a. Ras
: Mongoloid.
b. jenis kelamin : 3 laki-laki dan 1 perempuan.
c. deskripsi
cranium perempuan
2 calvarium laki-laki utuh
1 cranium laki-laki pecah pada bagian occipital sebelah kanan.
1 di antara 3 calvarium laki-laki mempunyai pathologi pada bagian frontal.

\section{Kelompok B}

Terletak di tingkat satu ceruk dinding gua sebelah sisi baratlaut, tepatnya di bawah kelompok A. Terdiri dari 2 buah tengkorak manusia yang berjajar dan dicirikan sebagai berikut ini:
a. Ras
Mongoloid.
b. jenis kelamin : 2 laki-laki.
c. deskripsi : 1 cranium pecah bagian parietal belakang.

\section{Kelompok $C$}

Terletak di tingkat dua ceruk dinding gua sebelah sisi tenggara. Terdiri dari 1 buah tengkorak manusia yang utuh, dan dicirikan sebagai berikut ini:
a. Ras
Mongoloid.
b. jenis kelamin : laki-laki.
c. deskripsi : cranium utuh. 


\section{Kelompok $D$}

Terletak di tingkat satu ceruk dinding gua sebelah sisi tenggara. Terdiri dari 2 buah tengkorak manusia, satu di sisi sebelah baratdaya, sedangkan yang lainnya di sisi timur laut. Adapun tengkorak tersebut dicirikan sebagai berikut ini:
a. Ras
Mongoloid.
b. jenis kelamin :
2 laki-laki.
c. deskripsi
cranium di sisi baratdaya terdapat lubang pada bagian occipital dan parietal kanan.
cranium di sisi timurlaut pecah pada bagian occipital dan parietal kanan.

\section{Kelompok $E$}

Terletak di dalam peti kayu (tebela) di dekat mulut gua. Kondisi tebela sudah runtuh di bawah dan sudah terpisah dari kayu penyangganya. Peti kayu mempunyai ukuran panjang sekitar $180 \mathrm{~cm}$ dengan lebar sekitar $35 \mathrm{~cm}$. Pada bagian peti kayu terdapat lubang sedalam $20 \mathrm{~cm}$. Adapun tutupnya lebih lebar dan panjang sekitar $50 \mathrm{~cm}$ dan $250 \mathrm{~cm}$. Peti kayu tersebut ditopang oleh dua buah tiang berukuran tinggi $150 \mathrm{~cm}$ dan garis tengah $25 \mathrm{~cm}$. Di dalam tebela tersebut terdapat sejumlah tengkorak dan rangka manusia yang dapat dijabarkan di bawah ini:
a. Ras
b. jenis kelamin :
c. deskripsi

Mongoloid.

2 perempuan, sisanya tidak jelas.

3 atap tengkorak, yang terdiri 1 bagian frontal, parietal dan muka, 1 berupa bagian frontal, parietal kanan dan sebagian parietal kiri, serta satunya lagi berupa atap tengkorak bagian depan.

2 buah tulang pinggul (coxa) yang relatif utuh.

1 buah femur kiri

I buah radius kiri

1 buah distal tibia

6 mandibula yang berupa: tiga buah berusia lanjut (dicirikan oleh alveolaris yang sudah tertutup, tanpa gigi); sebuah berciri dewasa lanjut; sebuah berupa anak-anak berusia 5 tahun; sebuah bercirikan dewasa lanjut serta mutilasi gigi pada dua gigi taring (canin).

\section{Kelompok $F$}

Terletak di dalam tempayan keramik kurang lebih satu meter di sebelah timurlaut kelompok E. Di sini terdapat dua tempayan yang sudah runtuh di bawah dan keramik sudah dalam keadaan pecah. Pendataan tahun 1992 oleh Kantor Departemen 
Pendidikan dan Kebudayaan Tabalong menujukkan kondisi yang masih utuh. Hasil rekonstruksi menunjukkan bahwa keramik pertama diletakkan di atas sebuah tiang penyangga dari kayu ulin setinggi kurang lebih 1 meter, dan bergaris tengah $20 \mathrm{~cm}$. Cara meletakkan keramik di atas tiang panyangga melalui teknik pelobangan pada bagian dasar keramik untuk ditancapkan pada ujung atas tiang, adapun bagian atasnya ditutup dengan kayu berbentuk bundar. Masyarakat suku Dayak menyebutkan bentuk ini dengan nama kariring. Di dalam tempayan inilah di simpan tengkorak manusia vang dapat dijelaskan sebagai berikut ini:
a. Ras
Mongoloid.
b. jenis kelamin : tidak jelas.
c. deskripsi : 1 buah fragmen tengkorak yang terdiri dari bagian parietal kanan.
d. kondisi : baik tempayan maupun tiang penyangganya sudah berserakan, sudah tidak ditempat semula.

Tidak jauh dari kariring tersebut terdapat pula sebuah tempayan yang ditopang oleh empat tiang penyangga dari kayu ulin. Selain itu ditemukan pula sebuah piring yang menurut informasi digunakan sebagai tutup tempayan. Masyarakat setempat menyebutkannya dengan nama teloh. Di dalam tempayan tersebut diletakkan tengkorak manusia yang dapat dijelaskan sebagai berikut ini:
a. ras
Mongoloid
b. jenis kelamin :
tidak jelas
c. deskripsi
sebuah fragmen tengkorak terdiri dari bagian occipital.
d. kondisi
baik tempayan maupun tiang penyangganya sudah berserakan, sudah tidak ditempat semula.

\section{Kelompok $\mathrm{H}$}

Terletak di sebuah ceruk yang agak dalam pada dinding sisi baratdaya bagian atas. $\mathrm{Di}$ dalam ceruk tersebut terdapat dua buah sisa-sisa tulang manusia yang ditelakkan di bagian lekukan dinding ceruk. Adapun tulang tersebut dicirikan sebagai berikut ini:
a. Ras
b. jenis kelamin
c. deskripsi

Mongoloid.

tidak jelas.

di dinding ceruk sebelah baratdaya terdapat 1 buah tulang kering (coxa kiri dan 1 buah humerus kiri. Adapun di dinding ceruk sebelah timurlaut terdapat sebuah tibia kiri dan sebuah fragmen femur di bagian diaphysis kanan. 


\section{Penutup}

Dari uraian di atas, terlihat bahwa Kabupaten Tabalong di Kalimantan Selatan mempunyai peluang dalam pengembangan penelitian prasejarah dan tradisinya, terutama yang menyangkut tinggalan dari tingkatan mesolitik (Gua Babi) dan tradisi pemujaan leluhur (Dayak Lawangan). Dalam lingkup pandangan yang lebih luas, Gua Babi merupakan salah satu potensi kuat ke arah pemahaman hunian gua di awal Kala Holosen, yang dapat menjembatani akan eksistensi budaya semasa di wilayah Indonesia bagian barat dan timur. Bukti-bukti mengenai permukiman manusia di guagua prasejarah yang paling sering ditemukan di Kalimantan adalah pecahan-pecahan tembikar, peralatan batu, dan tatal-tatalnya, serta cangkang-cangkang kerang yang merupakan sisa makanan, yang ditemukan sejauh ini di kaki Pegunungan Muller (Kalimantan Timur) dan Pegunungan Meratus (Kalimantan Timur). Beberapa di antaranya dilaporkan oleh para peneliti telah mengandung bukti mengenai bekasbekas perapian yang dikelilingi oleh sisa-sisa abu (Widianto, 1995). Survei yang telah kami lakukan di daerah Sangkulirang telah berhasil mengidentifikasi cap-cap tangan, yang juga ditemukan di Tanjung Mangkalihat, di sebelah timurnya (Prasetyo dan Kosasih, 1996).

Cap-cap tangan seperti ini banyak ditemukan di pulau-pulau sebelah timur Garis Wallacea. Suatu perbandingan dengan data arkeologi sejenis dari situs-situs gua di Sulawesi Selatan menunjukkan keterkaitan budaya secara erat. Hal ini menimbulkan suatu hipotesis tentang migrasi masa lalu antara Kalimantan dan Sulawesi, dan kemungkinan Garis Wallacea --pada bentang yang paling sempit antara daerah Sangkulirang dan Mangkalihat-- telah diseberangi manusia pada tingkatan mesolitik, sekitar akhir glasiasi terakhir.

Dalam tingkatan yang berbeda, tradisi penguburan pada masyarakat Dayak Lawangan di Kabupaten Tabalong juga menunjukkan potensi ke arah konotasi prasejarah, yang dalam hal ini mengacu pada pemujaan arwah lelulur yang berakar pada konsepkonsep megalitik. Pemujaan terhadap arwah leluhur tersebut secara jelas tercermin dalam konsep kematian yang mereka miliki, yang berdampak kuat terhadap praktekpraktek penguburan mereka. Setelah kematian, roh harus kembali ke tempat asalnya untuk hidup secara abadi di sana. Tempat-tempat pengburan sekunder lengkap dengan tata cara pendiriannya, adalah bagian integral dari nafas-nafas kehidupan Suku Dayak Lawangan yang sama sekali tidak dapat dipisahkan dari konsep pemujaan leluhur dalam kepercayaan Kaharingan mereka, dan konsep pandangan kekuatan supranatural dari masa prasejarah (Handini et al., 1997). 


\section{KEPUSTAKAAN}

Handini, Retno, Harry Widianto, dan Nasruddin, 1997. Laporan Penelitian Arkeologi : Tradisi Prasejarah pada Masyarakat Dayak Lawangan dan Dayak Maanyan di Kecamatan Dusun Tengah, Kabupaten Barito Selatan, Provinsi Kalimantan Tengah. Jakarta : Bidang Prasejarah Puslit Arkenas. Belum diterbitkan.

Nasruddin, 1996. Laporan Ekskavasi Jambu Hilir, Kabupaten Hulu Sungai Selatan, Kalimantan Selatan. Balai Arkeologi Banjarmasin, belum diterbitkan.

Prasetyo, Bagyo dan Harry Widianto 1996. Laporan Survei Prasejarah di Pegunungan Meratus, Kalimantan Selatan. Balai Arkeologi Banjarmasin, belum diterbitkan.

Prasetyo, Bagyo dan E.A Kosasih, 1996. Survei Gua-gua di Pegunungan Muller, Kecamatan Sangkulirang, Kabupaten Kutai, Kalimantan Timur. Laporan Penelitian Arkeologi, Balai Arkeologi Banjarmasin. Belum diterbitkan.

Soejono, R.P. (editor), 1984. Sejarah Nasional Indonesia I. Jakarta: Balai Pustaka.

Widianto, Harry, 1995. Eksplorasi Arkeologi di Kalimantan : hasil-hasil Pokok untuk Indonesia Tengah. Seminar Arkeologi oleh Ambassade de France dan Pusat Penelitian Arkeologi Nasional di Yogyakarta.

Widianto Harry, Truman Simanjuntak, dan Budianto Toha, 1997. Ekskavasi Situs Gua Babi. Kabupaten Tabalong, Provinsi Kalimantan Selatan, Berita Penelitian Arkeologi No. 01, Balai Arkeologi Banjarmasin. 